ROZDZIAE 3

\title{
Model programu rewitalizacji na poziomie lokalnym
}

Prezentowany $\mathrm{w}$ tym rozdziale model jest propozycją autorska, opartą na doświadczeniach wyniesionych $\mathrm{z}$ udziału $\mathrm{w}$ pracach $\mathrm{w}$ zakresie przygotowania Lokalnych Programów Rewitalizacji, programów rewitalizacji dla terenów pilotażowych, analiz zagranicznych przykładów tego typu opracowań oraz krajowych propozycji rozwiązań w tym zakresie. Należy zaznaczyć, że opracowanie niniejszej książki wyprzedziło prace prowadzone przez Instytut Rozwoju Miast $\mathrm{w}$ ramach grantu dotyczącego rewitalizacji miast polskich, podczas których zaproponowano także model procesu rewitalizacji ${ }^{1}$.

\subsection{Rewitalizacja jako proces planowania strategicznego}

Przede wszystkim należy stwierdzić, że proces rewitalizacji jest procesem długofalowym i złożonym, wymagającym stałego monitorowania stopnia realizacji założonych celów oraz określania nowych zadań i metod ich osiaggania $\mathrm{w}$ zmieniających się warunkach. Proces rewitalizacji bazuje na założeniach zarządzania strategicznego, możemy więc przyjąć, że ogólny model programu rewitalizacji bazować będzie na modelu procesu zarządzania strategicznego.

Proces zarządzania strategicznego zakłada podjęcie następujących kroków:

- Analiza zewnętrznego otoczenia - w rozumieniu otoczenia dalszego i bliższego (np. uwarunkowania prawne i polityczne gospodarki przestrzennej w kraju, sytuacja i poziom konkurencyjności gospodarki w jednostkach sąsiedzkich) oraz analizę jej sytuacji wewnętrznej określanej mianem otoczenia wewnętrznego (istniejący stan zagospodarowania przestrzennego, sytuacja społeczno-gospodarcza, sytuacja organizacyjna jednostek planujących i realizujących plany zagospodarowania przestrzennego). Analiza ta, nazywana analizą SWOT, pozwala określić szanse i zagrożenia (otoczenie zewnętrzne) oraz silne i słabe strony jednostki (otoczenie wewnętrzne), rozwiązania problemu, przeprowadzenie zmiany.

${ }^{1}$ K. Janas, W. Jarczewski, W. Wańkowicz, Model rewitalizacji miast, Rewitalizacja miast polskich, t. 10, Kraków 2010. 
- Określenie strategicznych celów społeczno-gospodarczego rozwoju jednostki i kierunków zagospodarowania przestrzennego.

- Wybranie możliwych rozwiązań zapewniających osiaggnięcie założonych celów strategicznych.

- Wdrożenie decyzji strategicznych.

- Przegląd osiągniętych rezultatów po zrealizowaniu celu.

- Powrót do analizy otoczenia i sytuacji wewnętrznej².

Na bazie powyższej struktury i wniosków wynikających z wymienionych na wstępie innych doświadczeń i źródeł proponuje się następujący model programu rewitalizacji, którego składowe zostaną omówione w dalszej części niniejszego rozdziału:

- Faza wyboru obszaru i analiz sytuacji wyjściowej: wyznaczanie granic obszaru rewitalizacji. Obszary pilotażowe. Badania wstępne. Diagnoza obszaru rewitalizacji.

- Faza formułowania celów strategicznych: definiowanie priorytetów rewitalizacji.

- Faza planowania i doboru działań oraz instrumentów służących realizacji celów strategicznych: określenie zadań/projektów rewitalizacji - plan działań. Plan docelowy.

- Faza realizacji założonych zadań: Harmonogram działania. Organizacyjne rozwiązania zarządzania procesem rewitalizacji. Proponowane działania promocyjne i mające na celu realizację partycypacji społecznej. Finansowanie procesu rewitalizacji.

- Faza oceny realizacji i aktualizacja programu: monitoring i ewaluacja efektów procesu rewitalizacji. System aktualizacji działań

\subsection{Wyznaczanie granic obszaru rewitalizacji. Obszary pilotażowe}

Pierwszym krokiem w kierunku podjęcia procesu rewitalizacji jest identyfikacja rejonów miasta charakteryzujących się szczególną koncentracją objawów degradacji przestrzennej, społecznej i gospodarczej. Wstępne wyznaczenie takich rejonów odbywa się na bazie dostępnych opracowań planistycznych (w tym przede wszystkim Studium uwarunkowań i kierunków zagospodarowania przestrzennego gminy, w którym wyznaczane są obszary „wymagające przekształceń, rehabilitacji lub rekultywacji”’3), wniosków od mieszkańców i właścicieli nieruchomości zebranych przez gminę oraz zapoznania się z sytuacją bieżącą $\mathrm{w}$ zakresie stanu zabudowy i środowiska miejskiego, symptomów patologii społecznych i marginalizacji gospodarczej bezpośrednio w terenie.

\footnotetext{
${ }^{2}$ W. M. Gaczek, Zarzqdzanie w gospodarce przestrzennej, Poznań 2003.

${ }^{3}$ Art. 10 pkt. 2, Ustawa z dnia 27 marca 2003 r. o planowaniu i zagospodarowaniu przestrzennym (DzU 2003, nr 80).
} 
$\mathrm{Na}$ tej podstawie dokonuje się wstępnego wyboru obszarów potencjalnie kwalifikujących się do objęcia programem rewitalizacji. Aby uzyskać weryfikację podjętych decyzji i możliwość dokładnej delimitacji obszarów, przeprowadza się analizy pod kątem spełniania przez nie odpowiednich kryteriów, wskazujących na przekraczające przeciętne dla miasta wskaźniki poziomu zjawisk kryzysowych. Kryteria identyfikacji obszarów kryzysowych zostały przedstawione w rozdz. 2.4.

Wielkość i złożoność terenów wyznaczonych w ten sposób wyklucza zazwyczaj możliwość prowadzenia działań kompleksowej rewitalizacji na całym obszarze - ze względów finansowych, organizacyjnych i merytorycznych. Tereny te często charakteryzują się bardzo zróżnicowaną strukturą wewnętrzną oraz występowaniem zarówno różnorodnych problemów środowiskowych, funkcjonalnych, społecznych i gospodarczych, jak i różnymi walorami lokalizacyjnymi i rozwojowymi. Takie zróżnicowanie obszarów wymaga dla każdego z nich określenia różnych priorytetów działań rewitalizacji.

Dlatego też częstą praktyką jest wyznaczanie tzw. „obszarów pilotażowych", na których skupia się środki i działania, tak aby osiagnąć w stosunkowo krótkim czasie widoczne pozytywne efekty procesu rewitalizacji. Obszary pilotażowe powinny charakteryzować się występowaniem nasilonych zjawisk kryzysowych, ale jednocześnie posiadać istotne potencjały, które umożliwią osiagnięcie maksymalnej efektywności działań rewitalizacyjnych. Obszary te mają pełnić funkcję „siły napędowej” procesów odnowy, a ich oddziaływanie na sąsiednie rejony ma doprowadzić do stopniowego rozszerzania się pozytywnych zjawisk regeneracji na coraz większy teren, obejmując w końcowym efekcie cały wyjściowy obszar kryzysowy. Koncentracja środków finansowych i działań na niewielkim wyznaczonym obszarze pilotażowym rewitalizacji ma wywołać tzw. „efekt kuli śniegowej” (spill-over $)^{4}$.

\subsection{Badania wstępne}

W programach rewitalizacji analiza uwarunkowań zewnętrznych i wewnętrznych procesu rewitalizacji jest elementem o zasadniczym znaczeniu. W krajach, w których działania związane z rewitalizacją przeprowadzane są od kilkudziesięciu lat - takich jak USA, Wielka Brytania, Francja czy Niemcy, opracowuje się, na wstępie prac związanych z tworzeniem programów rewitalizacji, ekspertyzy i zestawienia dotyczące barier infrastrukturalnych, przestrzennych, środowiskowych, instytucjonalnych, planistycznych, prawnych, społecznych i rynkowych, a także związanych z zarządzaniem mediami w programach rewitalizacji. W Niemczech badania przygotowawcze do programu rewitaliza-

\footnotetext{
${ }^{4}$ Patrz też: rozdz. 2.1 .
} 
cji - obejmujące analizę sytuacji społecznej, gospodarczej i przestrzennej - są wymagane ustawowo, stanowiąc podstawę budowy koncepcji programu rewitalizacji ${ }^{5}$.

W Polsce, w sytuacji braku ustawy o rewitalizacji, podstawą formalną regulującą kwestie zasad tworzenia programów rewitalizacji dla potrzeb pozyskiwania funduszy strukturalnych UE było do $2006 \mathrm{r}$. Uzupełnienie Zintegrowanego Programu Operacyjnego Rozwoju Regionalnego 2004-2006 (ZPORR), w którym zaproponowano strukturę lokalnego programu rewitalizacji, obejmującą m.in. analizę stanu istniejącego $\mathrm{w}$ aspekcie przestrzenym, społecznym i gospodarczym. Obecnie cele rewitalizacji i jej przedmiot określają programy regionalne - w przypadku województwa łódzkiego Regionalny Program Operacyjny Województwa Łódzkiego 2007-20136.

Badania wstępne, plan docelowy oraz plan działań stanowią powszechnie stosowane $\mathrm{w}$ praktyce niemieckiej instrumenty wykorzystywane na potrzeby planowania $\mathrm{w}$ obszarach rewitalizacji. Badania wstępne są instrumentem przygotowawczym, plan docelowy - instrumentem planowania, a plan działań instrumentem wdrażania ${ }^{7}$.

Badania wstępne obejmują: inwentaryzację urbanistyczną, analizę stanu infrastruktury technicznej, zasobów dziedzictwa kulturowego oraz analizy środowiskowe, gospodarcze i społeczne. Na bazie badań wstępnych oraz analiz SWOT wykonanych $\mathrm{w}$ poszczególnych obszarach kryzysowych określane są obszary pilotażowe. Badania wstępne stanowią także podstawę dla określenia priorytetów rewitalizacji.

Analiza SWOT oraz badania wstępne tworzą ponadto tzw. punkt zerowy określający stan wyjściowy poszczególnych parametrów w obszarze rewitalizacji będący punktem odniesienia dla prowadzonych $\mathrm{w}$ procesie rewitalizacji działań monitorujących.

Diagnoza obszaru rewitalizacji powstaje $w$ efekcie analizy danych pozyskanych $\mathrm{w}$ trakcie badań wstępnych, a także przeprowadzonej przez doświadczonego urbanistę identyfikacji występujących w obszarze deficytów i konfliktów przestrzennych i funkcjonalnych. Zaobserwowane deficyty dotyczą przede wszystkim kwestii: braku odpowiedniego zagospodarowania terenów użytkowanych i nieużytkowanych, zaniedbań w stanie technicznym obiektów, nieodpowiedniego urządzenia przestrzeni publicznej, braku i zaniedbań w zakresie wyposażenia placów zabaw dla dzieci, uciążliwości ze strony istniejącego układu komunikacyjnego, $\mathrm{w}$ tym braku właściwie zorganizowanego parko-

${ }^{5}$ W Niemczech ustawa o rewitalizacji stanowi część ustawy o planowaniu przestrzennym: Baugesetzbuch, Besonderes Staedtebaurecht, 2004.

${ }^{6}$ Zagadnienia związane $\mathrm{z}$ rewitalizacją ujęte $\mathrm{w}$ strategicznych dokumentach krajowych i regionalnych przedstawione zostały w rozdziale 7 niniejszego opracowania.

${ }^{7}$ BIG Staedtebau: G. Adamczyk-Arns, A. Wojnarowska, E. Feresztyn, F. Hultsch, F. Hultsch, Miejski Program Rewitalizacji Krakowa, październik 2008, www. rewitalizacja.krakow.pl. 


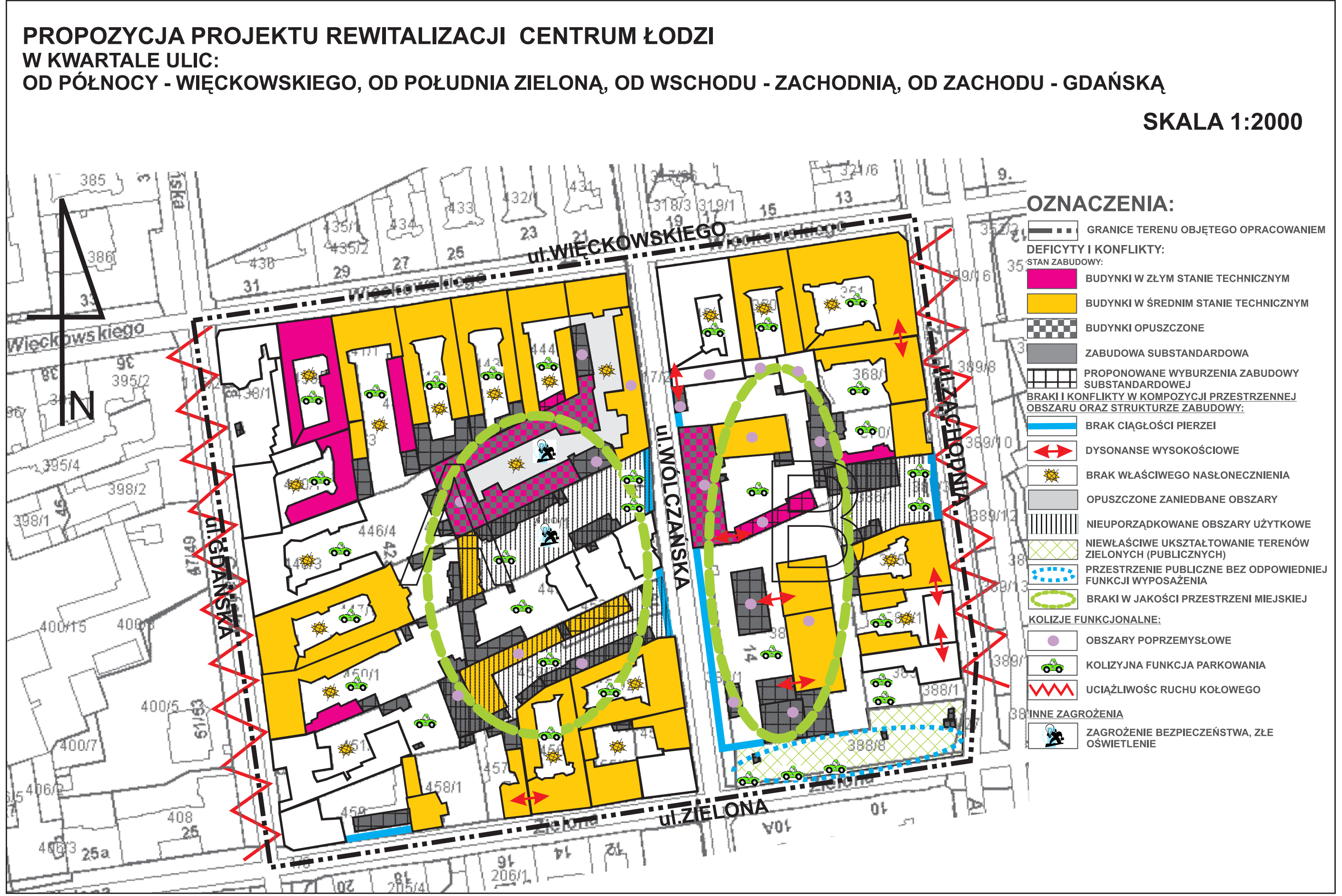

Rys. 1. Badania przygotowawcze - identyfikacja deficytów i konfliktów w obszarze rewitalizacji

Źródło: Praca studencka pt. Propozycja projektu rewitalizacji zespołu urbanistyczno-architektonicznego kwartału ulic w centrum Łodzi: Więckowskiego, Gdańska, Zielona, Zachodnia, wykonana na kierunku Gospodarka Przestrzenna na Wydziale Nauk Geograficznych Uniwersytetu Łódzkiego w roku akademickich 2008/2009, w ramach przedmiotu Rewitalizacja obszarów zdegradowanych przez zespół autorski w składzie: Katarzyna Drążczyk, Alicja Jaranowska, Ewa Koprowska, Rafał Ulaski, pod kier. dr inż. arch. Anny Wojnarowskiej 
wania, występowania luk, nieciągłości oraz dysonansów w zabudowie, braku przejść dla pieszych, osi widokowych i dominant przestrzennych, braków w zakresie bezpieczeństwa publicznego, złych powiązań przestrzennych i funkcjonalnych, niewłaściwego doświetlenia i przewietrzania obiektów itd.

Diagnoza przygotowywana jest $\mathrm{w}$ formie opisowej i graficznej. Istotny element części graficznej diagnozy stanowi mapa deficytów obszaru (rys. 1) opracowana w przystępnej dla nieprofesjonalnych odbiorców formie graficznej, służąca także prezentacji zidentyfikowanych deficytów w trakcie konsultacji społecznych - warsztatów planistycznych - we wstępnej fazie programu rewitalizacji.

\subsection{Definiowanie priorytetów rewitalizacji}

Priorytety rewitalizacji to, inaczej mówiąc, główne cele rewitalizacji, które wyznaczaja podstawowe kierunki założonych działań naprawczych. Cele te zazwyczaj odzwierciedlają trzypłaszczyznową strukturę programu rewitalizacji, w związku z czym możemy wyróżnić priorytety w zakresie przestrzennym, społecznym i gospodarczym.

Można dokonać również innego podziału priorytetów - ze względu na charakter zagadnień, jakie obejmują. Priorytety stałe są to te cele rewitalizacji, które leżą w gestii władz lokalnych i wynikają z założonej polityki miasta w zakresie rozwoju społeczno-gospodarczego, ochrony środowiska i zasobów dziedzictwa kulturowego, rozwoju turystyki.

Priorytety zmienne tworzone są natomiast na bazie analizy popytu inwestorów na nieruchomości w poszczególnych obszarach ${ }^{8}$.

\subsection{Określenie zadań/projektów rewitalizacji - plan dzialań}

Plan działań to całościowe zestawienie założonych w programie rewitalizacji zadań i projektów, określonych wcześniej w planie docelowym, w którym definiuje się wszystkie proponowane zadania rewitalizacji - w zakresie budowlanym, technicznym, komunikacyjnym, środowiskowym, ochrony dziedzictwa kulturowego, społecznym i gospodarczym. Określenie poszczególnych zadań umożliwia ich planowanie i koordynację w ramach przewidywanego harmonogramu, a także oszacowanie niezbędnych nakładów finansowych sektora publicznego i prywatnego. Plan działań opracowuje się dla całego obszaru, przy zastosowaniu ewentualnego podziału na podobszary w przypadku większych rejonów poddawanych rewitalizacji. Jest on opracowany zarówno $\mathrm{w}$ formie opisowej i tabelarycznej, jak i w postaci rysunku pokazującego lokalizacje

\footnotetext{
${ }^{8}$ BIG Staedtebau, Konkurs na LPR Krakowa, 2006.
} 
poszczególnych proponowanych zadań i projektów o charakterze przestrzennym, inne czynności - z zakresu problematyki społecznej i gospodarczej, są przedstawiane jedynie w formie opisowej (rys. 2).
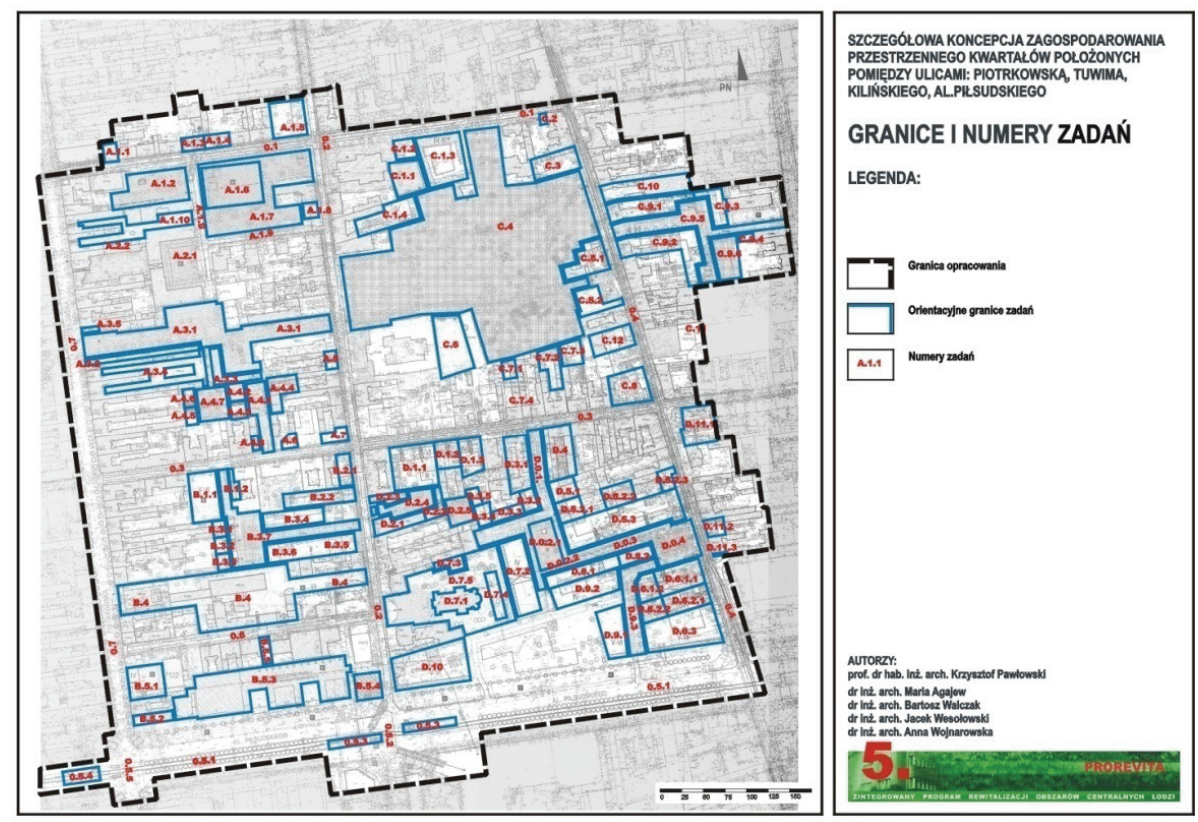

Rys. 2. Szczegółowa koncepcja zagospodarowania kwartałów położonych pomiędzy ulicami: Piotrkowska, Tuwima, Kilińskiego, al. Piłsudskiego - granice i numery zadań

Źr ó d ł o: K. Pawłowski, M. Agajew, B. Walczak, J. Wesołowski, A. Wojnarowska, Szczegółowa koncepcja programowo-przestrzenna zagospodarowania terenu. Obszar poludniowy rewitalizacji, [w:] Zintegrowany Program Rewitalizacji Obszarów Centralnych Łodzi Etap II, Łódź 2005

\subsection{Plan docelowy}

Elementem nowym w stosunku do polskich opracowań związanych $\mathrm{z}$ rewitalizacją, nie mającym też odpowiednika w polskim systemie planowania przestrzennego, jest plan docelowy. Plan docelowy nazywany jest w Niemczech także strategicznym planem rozwoju lub ramowym planem urbanistycznym.

Planowanie procesów odnowy miast w krajach zachodniej Europy co najmniej od lat siedemdziesiątych XX w. jest postrzegane nie jako tworzenie całościowych, zamkniętych długofalowych planów, które mogłyby być wdrażane bez konieczności aktualizacji, lecz jako ustawiczne sterowanie procesem odnowy miast, który musi być w sposób ciągły dostosowywany do zmieniają- 
cych się potrzeb i wymagań. Plan docelowy (Masterplan) jest stosowany jako narzędzie planistyczne $\mathrm{w}$ wielu krajach europejskich i praktyka potwierdziła jego właściwe, pozytywne dla procesów rozwojowych miasta funkcjonowanie. Treść takich planów często nie ma oparcia w konkretnych ustawach, może więc być elastycznie dopasowywana do zmieniających się uwarunkowań i wymagań. Plan docelowy nie zastępuje miejscowego planu zagospodarowania przestrzennego, którego sporządzenie dla obszaru rewitalizacji w warunkach polskich jest konieczne, ponieważ zapewnia realizację zamierzeń rewitalizacyjnych jako dokument stanowiący prawo miejscowe?

Plan docelowy sporządzany jest w czytelnej, przystępnej dla nieprofesjonalnego odbiorcy formie graficznej i umożliwia dzięki temu poglądową prezentację planowanych zmian i faktyczne włączenie mieszkańców w procesy planowania urbanistycznego. Plan docelowy pełni także rolę planu inwestycyjnego i odgrywa dzięki temu dużą rolę $\mathrm{w}$ możliwości ubiegania się o środki pomocowe. Ze względu na swoje znaczenie dla rozwoju przestrzenno-funkcjonalnego miasta, plan docelowy musi zostać zatwierdzony uchwałą Rady Miasta.

Jak wskazują doświadczenia związane ze sporządzaniem planów docelowych w dużych miastach europejskich, powinny być to plany robocze, tworzone dla poszczególnych dzielnic lub zbliżonych wielkością obszarów. Umożliwiłyby one wypełnienie luki w skali i problematyce pomiędzy studium uwarunkowań i kierunków zagospodarowania przestrzennego a miejscowym planem zagospodarowania przestrzennego oraz całościowe ujęcie złożonych problemów urbanistycznych w szerszym kontekście przestrzennym, niż sporządzany dla niewielkiego obszaru plan miejscowy ${ }^{10}$.

Plan docelowy ma za zadanie określenie wspótistnienia w wyznaczonym fragmencie struktury miejskiej różnorodnych funkcji, co umożliwia powiązanie poszczególnych projektów dla uzyskania efektu synergii. Jest on ponadto dokumentem określającym długofalową politykę miasta dla danego obszaru, co stanowi istotną wskazówkę i oparcie w podejmowaniu decyzji przez inwestorów.

Plan docelowy składa się z wielu, adekwatnych do potrzeb danego obszaru, planów cząstkowych. Standardowymi planami cząstkowymi są:

1) plan stanu istniejącego - plan analityczny,

2) plan funkcji użytkowych - koncepcja docelowa,

3) plan systemu komunikacji - koncepcja docelowa,

4) plan realizacji - koncepcja docelowa,

5) projekty testowe - koncepcja docelowa;

Planami cząstkowymi dopasowanymi do specyfiki obszaru mogą być też:

6) plan lokalizacji handlu detalicznego - koncepcja docelowa,

7) plan lokalizacji podmiotów gospodarczych - koncepcja docelowa,

\footnotetext{
${ }^{9}$ BIG Staedtebau GmbH, Miejski... s. 5.

${ }^{10}$ Tamże, s. 33.
} 


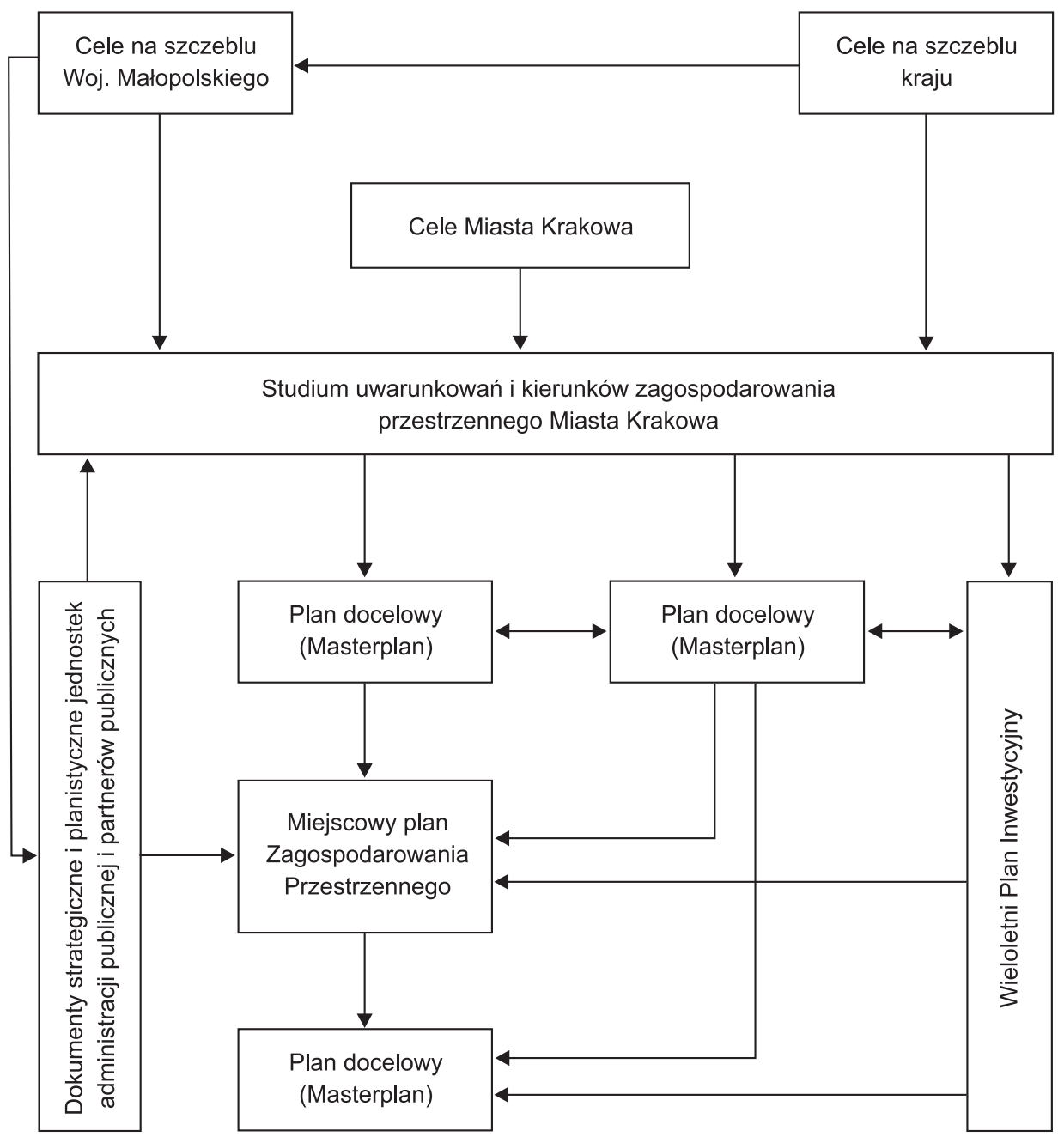

Ryc. 3. Propozycja włączenia planu docelowego rewitalizacji w polską strukturę planowania przestrzennego

Źr ó d ł o: Oprac. A. Wosiak na podstawie Miejski Program Rewitalizacji Krakowa, s. 43 
8) plan zieleni miejskiej - koncepcja docelowa,

9) docelowy plan ochrony zabytków,

10) plany rozbudowy infrastruktury technicznej,

11) plan wizerunku miasta,

12) inne, specyficzne ze względu na lokalne uwarunkowania ${ }^{11}$.

\subsection{Harmonogram dzialań}

W tej części programu rewitalizacji określa się etapy planowanych działań dla całościowego programu rewitalizacji oraz w ramach poszczególnych rodzajów działań $^{12}$, a także zestaw zadań przewidzianych do realizacji w ramach tych działań.

Prawidłowe zaprogramowanie działań umożliwia ich właściwą koordynację i płynność w realizacji programu.

\subsection{Organizacyjne rozwiązania zarządzania procesem rewitalizacji}

Dla zarządzania programem rewitalizacji tworzone są jednostki wyposażone w różne kompetencje, wdrażające i koordynujące przewidziane działania:

- Operator rewitalizacji - jednostka organizacyjno-prawna odpowiedzialna za proces przekształceń dokonywanych na rewitalizowanym terenie, którego podstawą działania jest odpowiednia umowa z Urzędem Miasta.

- Zespół nadzorujący proces rewitalizacji - złożony z przedstawicieli władz miasta, ekspertów i mieszkańców rewitalizowanego obszaru.

- Zespół konsultacyjno-informacyjny - złożony z przedstawicieli poszczególnych zaangażowanych w proces rewitalizacji wydziałów Urzędu Miasta.

- Komitet monitorujący realizację programu rewitalizacji ${ }^{13}$.

W proces rewitalizacji zaangażowani są różni ,aktorzy“, współdziałający w zakresie jego przygotowania, wdrażania, monitorowania i aktualizacji reprezentanci władz miejscowych, społeczności lokalnych i właścicieli nieruchomości, operatora ds. rewitalizacji, przedstwiciele organizacji i stowarzyszeń politycznych, gospodarczych i społecznych, potencjalni inwestorzy. Do koordynacji działań wszystkich uczestników procesu wskazana jest budowa struktury organizacyjnej, składającej się z organu doradczego i zespołu roboczego ds.

\footnotetext{
${ }^{11}$ Tamże, s. 33.

${ }^{12} \mathrm{~Np}$. w ramach polityki mieszkaniowej, polityki obsługi turystycznej i organizacji wolnego czasu, analizy stanu własności nieruchomości, programu rozwoju przedsiębiorczości itd. Za: T. Markowski, D. Stawasz, A. Nowakowska, Harmonogram wdrażania programu, [w:] Zintegrowany Program Rewitalizacji obszarów centralnych Łodzi Prorevita. Etap II, Łódź 2005.

${ }^{13}$ T. Markowski, D. Stawasz, A. Nowakowska, Plan systemu okresowej aktualizacji dziatań, [w:] Zintegrowany Program Rewitalizacji...
} 
rewitalizacji. Do przygotowania i realizacji poszczególnych projektów powinny być również tworzone grupy robocze.

Organ doradczy ma za zadanie koordynować działania wszystkich uczestników procesu w ramach założonej strategii rewitalizacji. Ciało to dyskutuje nowe tendencje rozwojowe, bada oddziaływania przeprowadzonych projektów, przeprowadza dyskusje i głosowania nad propozycjami nowych projektów i ewentualnymi zmianami przyjętych w programie celów. W skład organu doradczego wchodzą: przedstawiciele władz lokalnych, związków i organizacji społecznych, właściciele nieruchomości, przedsiębiorcy i mieszkańcy.

Zespól roboczy składa się z przedstawicieli władz lokalnych oraz firmy operatorskiej ds. rewitalizacji i ma spotykać się regularnie w celu konsultacji założonych prac i koordynacji planowanych zadań. Urząd Miasta reprezentowany jest przez pełnomocnika ds. rewitalizacji, który zaprasza na poszczególne problemowe spotkania przedstawicieli odpowiednich merytorycznie wydziałów. Zespół roboczy opracowuje decyzje administracyjne i przedkłada je do akceptacji Radzie Miasta.

Na czas przygotowania i realizacji poszczególnych projektów tworzone są tzw. grupy robocze. W skład grup roboczych wchodzą stali członkowie oraz wszystkie podmioty i osoby zainteresowane tym projektem ${ }^{14}$.

Kontrola działań operatora rewitalizacji przez gminę odbywa się $\mathrm{w}$ formie spotkań informacyjnych z partnerami uczestniczącymi w programie rewitalizacji, sprawozdań opisujących prowadzone działania, uzyskiwane efekty, napotkane bariery, obejmujących informacje o kontaktach z inwestorami i rozwiązywaniu sytuacji konfliktowych ${ }^{15}$. Obowiązki i zadania firmy operatorskiej omówiono w rozdz. 3.6.

\subsection{Proponowane dzialania promocyjne i mające na celu realizację partycypacji spolecznej}

W celu promocji programu rewitalizacji oraz włączenia społeczności w proces planowania i wdrażania procesu rewitalizacji należy podjąć następujące działania:

- Udostępnianie informacji - ukierunkowana na budowanie tożsamości lokalnej promocja programu rewitalizacji.

Sprawą zasadniczej wagi jest dotarcie $\mathrm{z}$ informacją na temat planowanych i prowadzonych działań do wszystkich zaangażowanych w proces rewitalizacji grup odbiorców. W związku z tym należy stworzyć system informacji i wymiany opinii posiłkujący się różnymi formami przekazu (publikacje, broszury, plakaty, Internet, inne zwyczajowo przyjęte w danym miejscu formy ogłoszeń).

${ }^{14}$ BIG Staedtebau, Konkurs na LPR Krakowa, 2006.

${ }^{15}$ E. Zawadzki, Analiza funkcjonujacych programów modernizacyjnych miejskich zasobów mieszkaniowych i użyteczności publicznej, Biuro Studiów i Ekspertyz, Raport nr 164, 1999. 
Włączanie mieszkańców w proces rewitalizacji prowadzi do ich zwiększonej identyfikacji z obszarem działań i sprzyja wzrostowi świadomości tożsamości lokalnej.

- Warsztaty planistyczne - partycypacja mieszkańców w procesie planowania i wdrażania działań rewitalizacyjnych.

Planowane działania dla obszaru rewitalizacji należy wypracować przy współudziale poszczególnych grup uczestników procesu rewitalizacji. Taka współpraca powinna mieć formę warsztatów planistycznych i dotyczyć tematów bezpośrednio związanych $\mathrm{z}$ rozwiązywaniem problemów przestrzennych, społecznych i gospodarczych, takich jak: urządzanie podwórek, placów zabaw, miejsc spotkań młodzieży, przestrzeni publicznej i terenów zielonych, organizacja placówek socjalnych, wspieranie małych i średnich przedsiębiorstw, zakładanie działalności gospodarczej itp.

Włączenie społeczności lokalnej od początku w proces planowania i realizacji działań wzmacnia identyfikację $\mathrm{z}$ otoczeniem i przyczynia się do zmniejszenia wandalizmu. Stwarza to także możliwość przejęcia wykonania części prac (np. nasadzeń roślin) przez mieszkańców - jako przyszłych użytkowników rewitalizowanych obszarów.

\section{- Akcje spoleczne}

Realizacja wyżej wymienionych prac przebiegać powinna $w$ ramach zorganizowanych akcji społecznych (wystrój podwórek, akcje sadzenia drzew, pielęgnacji zieleni, porządkowanie przestrzeni publicznej, placów zabaw). Organizowane są także imprezy mające na celu wzmocnienie identyfikacji mieszkańców z dzielnica, takie jak święta ulicy oraz festyny dzielnicowe.

\section{- Kompleksowa oferta doradztwa dla najemców i właścicieli}

Należy uruchomić na obszarze rewitalizacji punkt informacyjny, w którym będą udzielane porady najemcom i właścicielom nieruchomości, a także przekazywane informacje na temat prowadzonych działań oraz odnośnie do możliwości uzyskania wsparcia dla właścicieli nieruchomości. Powinny być również organizowane warsztaty informujące o modelowych przykładach rewitalizacji, które mogłyby stanowić bodziec do opracowywania konkretnych projektów dla przedmiotowego obszaru.

\section{- Kompleksowa oferta doradztwa dla przedsiębiorców i inwestorów}

W ramach tego zespołu działań podejmowane są inicjatywy mające na celu długoterminowe zabezpieczenie inwestycji $\mathrm{w}$ danej lokalizacji, optymalizacja standardów nieruchomości oraz ich promocja na rynku. Organizowane są spotkania z przedstawicielami izb przemysłowo-handlowych i branży nieruchomości poświęcone omawianiu aktualnych tematów specjalistycznych. Dla zachęcenia inwestorów i przedsiębiorców do zaangażowania się $\mathrm{w}$ proces realizacji należy stworzyć system marketingowy, ukierunkowany na pozyskiwanie odpowiednich, przewidzianych $\mathrm{w}$ programie rewitalizacji branż, tworzenie systemu zachęt na rzecz zakładania działalności gospodarczej (dotacje). Docelowo takie działania powinny doprowadzić do likwidacji braków w ofercie 
usługowej rewitalizowanego obszaru i stworzyć korzystną i akceptowaną przez użytkowników konstelację funkcji użytkowych. Kolejnym zadaniem jest także prowadzenie systemu zarządzania przeprowadzkami zakładów przemysłowych $\mathrm{i}$ usługowych, spowodowanych prowadzonymi działaniami rewitalizacyjnymi ${ }^{16}$.

\subsection{Finansowanie procesu rewitalizacji}

Potrzeby finansowe związane $\mathrm{z}$ realizacją zamierzeń rewitalizacyjnych są zawsze tak duże, iż znacznie przekraczają możliwości ich pokrycia przez władze lokalne. W tej sytuacji fundusze publiczne zaangażowane $\mathrm{w}$ ten proces muszą być skierowane jedynie na realizację zadań, które nie mogą być podjęte przez inwestorów prywatnych. Dlatego też modele finansowania procesów rewitalizacji generalnie bazują na tzw. efekcie dźwigniowym (leverage effect), dzięki któremu zaangażowanie stosunkowo niewielkich środków finansowych miasta aktywizuje znaczne nakłady prywatnego sektora gospodarki oraz instytucji publicznych.

Wydatki władz lokalnych na rewitalizację muszą być planowane w ten sposób, aby stanowiły impuls przyczyniający się do podjęcia przez sektor prywatny znaczących przedsięwzięć inwestycyjnych. Do zadań, na które władze lokalne muszą przeznaczyć własne środki finansowe, należą działania niekomercyjne, często z grupy inwestycji celu publicznego: drogi publiczne, sieci i urządzenia infrastruktury technicznej, tereny zieleni i rekreacji, placówki administracji i obiekty infrastruktury społecznej. Najczęściej realizowanymi inwestycjami władz miejskich spoza grupy celów publicznych są działania zmierzające do modernizacji istniejących lub tworzenia nowych obszarów przestrzeni publicznej ${ }^{17}$. Przyjmuje się zasadę, że środki publiczne powinny być spożytkowane w taki sposób, aby w sposób najbardziej efektywny umożliwiły realizację celów publicznych, zaplanowanych $\mathrm{w}$ taki sposób, aby stworzyły ramy programu rewitalizacji i zachętę do angażowania się w proces rewitalizacji dla inwestorów prywatnych.

\footnotetext{
${ }^{16}$ BIG Staedtebau, Konkurs...

${ }^{17}$ Pojęcie przestrzeni publicznej zostało zdefiniowane w ustawie z dnia 27 marca $2003 \mathrm{r}$. o planowaniu i zagospodarowaniu przestrzennym (art. 2 ust. 6): „Przez obszar przestrzeni publicznej należy rozumieć obszar o szczególnym znaczeniu dla zaspokojenia potrzeb mieszkańców, poprawy jakości ich życia i sprzyjający nawiązaniu kontaktów społecznych ze względu na jego położenie oraz cechy funkcjonalno-przestrzenne, określony w studium uwarunkowań i kierunków zagospodarowania przestrzennego gminy". Realizacja inwestycji związanych $\mathrm{z}$ przestrzeniami publicznymi nie jest jednak celem publicznym w rozumieniu ustawy z dnia 21 sierpnia 1997 r. o gospodarce nieruchomościami (DzU 2004, nr 261 - tekst jednolity), co powoduje trudności w planowaniu i realizacji tych zamierzeń, $\mathrm{w}$ tym także $\mathrm{w}$ ramach przedsięwzięć przewidzianych $\mathrm{w}$ ramach programów rewitalizacji. Utrudnienia te wynikają m.in. z braku możliwości - w razie konieczności - uruchomienia procedury wywłaszczeniowej.
} 
Można wyróżnić cztery podstawowe formy instytucji finansowych zaangażowanych w proces rewitalizacji:

a) instytucje bezpośrednio przekazujące środki finansowe na cele rewitalizacji, takie jak: budżet państwa, budżety gminne, budżety regionalne - działające poprzez swoje agendy;

b) samodzielne publiczne podmioty gospodarcze - krajowe, regionalne i lokalne agencje rozwoju (rewitalizacji) ora prawnie wyodrębnione fundusze;

c) prywatne podmioty gospodarcze - banki, instytucje ubezpieczeniowe, instytucje leasingowe;

d) instytucje hybrydowe - banki i fundusze, w tym pożyczkowe i doręczeniowe, tworzone przez władze publiczne (krajowe, regionalne i lokalne) dla obsługi programów rządowych ${ }^{18}$.

Fundusze publiczne - państwowe i gminne - pochodzą zazwyczaj z powszechnych podatków, a także opłat czynszowych oraz środków uzyskanych w wyniku sprzedaży lokali. Gminy dla finansowania rewitalizacji mogą również wykorzystywać takie instrumenty finansowe, jak tworzenie środków finansowych w ramach agencji rewitalizacji miast, emisja obligacji w ramach pożyczek komunalnych, tworzenie remontowych funduszy gwarancyjnych, funduszy aktywizacji windykacji należności czynszowych itp. ${ }^{19}$

W celu realizacji złożonych przedsięwzięć rewitalizacyjnych konieczne jest stworzenie tzw. montażu finansowego, w którym łączy się środki finansowe pochodzące $\mathrm{z}$ różnych zewnętrznych i wewnętrznych źródeł finansowania. Źródła zewnętrzne to przede wszystkim: fundusze strukturalne Unii Europejskiej, kredyty Europejskiego Banku Inwestycyjnego, Banku Rozwoju Rady Europy, Europejskiego Banku Odbudowy i Rozwoju oraz ewentualnie Norweskiego Mechanizmu Finansowego i Mechanizmu Finansowego EOG. Programy kredytowe owych banków przeznaczone na odnowę miast powinny być wykorzystane $w$ ramach wdrażania instrumentów finansowych JESSICA, JEREMIE i JASPERS w celu przeprowadzenia zadań planowanych przez miasto ${ }^{20}$.

Inicjatywy Wspólnoty: JEREMIE, JASPERS i JESSICA zaproponowane zostały przez Komisję Europejską i Grupę Europejskiego Banku Inwestycyjnego dla okresu planowania 2007-2013. Inicjatywy te mają służyć wzmocnieniu absorpcji środków funduszy strukturalnych UE w państwach członkowskich ${ }^{21}$.

1. Inicjatywa JEREMIE (Joint European Resources for Micro to Medium Enterprise) ma służyć ułatwieniu dostępu do kapitału dla mikro-, małych

${ }^{18}$ I. Herbst, Warunki finansowania procesów rewitalizacji w gospodarce rynkowej, [w:] M. Bryx (red.), Finansowanie i gospodarka nieruchomościami w procesach rewitalizacji, Seria: Rewitalizacja Miast Polskich, t. 7, Kraków 2009, s. 142.

${ }^{19}$ E. Zawadzki, Analiza funkcjonujacych...

${ }^{20}$ BIG Staedtebau, Konkurs...

${ }^{21} \mathrm{http}: / / w w w . f u n d u s z e e u r o p e j s k i e . g o v . p 1 /$ 
i średnich przedsiębiorstw dzięki środkom finansowym Europejskiego Banku Inwestycyjnego.

2. Inicjatywa JASPERS (Joint Assistance in Supporting Projects in European Regions) to program pomocy technicznej (analizy, doradztwo, pomoc przy przygotowywaniu projektów, konsultacje) adresowany przede wszystkim do nowych państw członkowskich. W ramach tej inicjatywy wspierane mają być duże projekty infrastrukturalne (od $25 \mathrm{mln}$ euro w sektorze środowiska oraz od $50 \mathrm{mln} \mathrm{w}$ sektorze transportu i innych sektorach, które kwalifikują się do wsparcia z Europejskiego Funduszu Rozwoju Regionalnego oraz Funduszu Spójności). Dofinansowanie ma pochodzić ze środków Europejskiego Banku Inwestycyjnego.

3. Inicjatywa JESSICA (Joint European Support for Sustainable Investment in City Areas) ma na celu wspieranie inwestycji w zakresie zrównoważonego rozwoju na obszarach miejskich w krajach Unii Europejskiej. Dzięki środkom Europejskiego Banku Inwestycyjnego i Europejskiego Banku Odbudowy i Rozwoju instytucje zarządzające programami operacyjnymi będą mogły korzystać z usług ekspertów zewnętrznych, a także uzyskać kredyty na cele związane $\mathrm{z}$ rozwojem miejskim, w tym także mieszkalnictwo społeczne.

\subsection{Monitoring i ewaluacja efektów procesu rewitalizacji. System aktualizacji działań}

Monitoring ma na celu uzyskanie informacji na temat efektywności realizowanego programu rewitalizacji. W celu uzyskania prawidłowego działania systemu monitorowania, zalecane jest jego stworzenie przed przystąpieniem do wdrażania programu, a nie dopiero $\mathrm{w}$ toku jego realizacji. System monitoringu - stałej obserwacji ilościowych i jakościowych zmian - stanowić ma narzędzie umożliwiające modyfikację przyjętych na wstępie programu założeń i jego aktualizację - dostosowanie do zmieniających się uwarunkowań.

Monitoring ma na celu umożliwienie:

- oceny realizacji założonych zadań i osiagnniętych efektów,

- gromadzenie informacji o rewitalizowanych obszarach,

- bieżącej identyfikacji nowych zjawisk i procesów zachodzących w rewitalizowanych obszarach,

- obserwacji zmian trendów rozwojowych.

System monitorowania posługuje się określonym zestawem mierników. Należy podkreślić konieczność stosowania w przeprowadzanych pracach stosowania stałego zestawu wskaźników oraz odnoszenia ich do tego samego obszaru badań, w takich samych przyjętych okresach.

W ramach systemu monitorowania można określić następujące typy przeprowadzanych ocen: 
- ocena przed wykonaniem zadania - czyli ocena ex ante, służąca weryfikacji proponowanych działań pod kątem ich ekonomiczności, racjonalności i spójności z celami programu rewitalizacji;

- ocena bieżąca w trakcie realizacji zadania - ocena taka służy analizie postęów poszczególnych zadań w trakcie ich realizacji;

- ocena po wykonaniu zadania - ocena ex post umożliwiająca porównanie zakładanych i osiągniętych efektów danego działania ${ }^{22}$.

Autorzy cytowanego wyżej opracowania wyróżniają szereg rozłącznych kryteriów, charakteryzujących wskaźniki monitorowania:

- kryterium przedmiotowe (lub poziomu oddziaływania),

- kryterium celów rewitalizacji,

- kryterium mierzalności wskaźnika,

- kryterium szczegółowości wskaźnika.

Ze względu na kryterium przedmiotowe, można wyróżnić trzy rodzaje wskaźników: wskaźniki produktu, wskaźniki rezultatu i wskaźniki oddziaływania. Wskaźniki produktu odzwierciedlają postęp we wdrażaniu poszczególnych działań programu rewitalizacji. Bardziej ogólny charakter mają wskaźniki rezultatu, które mierzą bezpośrednie efekty finansowanych działań dla beneficjentów. Wskaźniki oddziaływania mają najbardziej ogólny charakter - obrazują one postęp w osiaganiu założonych celów programu rewitalizacji. Wskaźniki oddziaływania bezpośredniego odnoszą się do obszaru rewitalizacji, natomiast wskaźniki oddziaływania pośredniego służą ocenie oddziaływania programu rewitalizacji na całe miasto.

Podział wskaźników ze względu na kryterium celu odzwierciedla wielopłaszczyznowy charakter procesu rewitalizacji. Dlatego też można mówić o wskaźnikach celu $\mathrm{w}$ aspekcie społecznym, kulturowym, środowiskowym, gospodarczym oraz infrastrukturalnym.

Ze względu na kryterium mierzalności można wyróżnić: wskaźniki mierzalne (ilościowe) i wskaźniki niemierzalne (jakościowe) procesu rewitalizacji.

Natomiast zgodnie z kryterium szczegółowości, wskaźniki monitorowania można podzielić na wskaźniki podstawowe (ogólne) - służące szybkiej ocenie najistotniejszych elementów programu rewitalizacji oraz wskaźniki uzupełniające (szczegółowe) - do analizy poszczególnych sfer programu rewitalizacji.

$\mathrm{Za}$ prowadzenie monitoringu procesu rewitalizacji odpowiada operator rewitalizacji, przeprowadzając ocenę ex ante, ocenę bieżącą i ocenę ex post. Zaleca się, aby także władze lokalne uczestniczyły w procesie monitoringu, przede wszystkim w ocenie ex post wykonanych zadań. Zadania te realizuje Komitet Monitorujący, który dokonuje okresowej oceny realizacji procesu.

${ }^{22}$ T. Markowski, D. Stawasz, A. Nowakowska, M. Turała, Określenie sposobów monitorowania $i$ oceny. Koncepcja wskaźników ocen, wskaźników monitorowania procesu rewitalizacji - produktu, rezultatu, oddziaływania, [w:] Zintegrowany Program Rewitalizacji... 
Prowadzenie monitorowania zmian jakościowych i ilościowych zachodzących w obszarach rewitalizowanych, umożliwia okresową aktualizację działań przewidzianych do realizacji $\mathrm{w}$ ramach programu rewitalizacji. Do aktualizacji działań należy również wykorzystywać wnioski i uwagi ze strony lokalnej społeczności, gromadzone przez operatora rewitalizacji.

Ocena i aktualizacja programu działań w ramach procesu rewitalizacji powinna być realizowana dwojako:

a) ocena i aktualizacja bieżąca - realizowana dla poszczególnych zadań rewitalizacji, bazująca na raportach rocznych i końcowych po realizacji zadania oraz

b) ocena i aktualizacja długookresowa - ocena całego programu rewitalizacji pod kątem spójności podejmowanych działań i ich oddziaływania na rozwój miasta. Ocena ta powinna się odbywać w cyklu dwuletnim i pięcioletnim.

Sprawą pierwszoplanową w aktualizacji programu rewitalizacji jest uzyskanie szerokiej społecznej aprobaty dla proponowanych zmian:

Każda aktualizacja dokonana w ramach programu rewitalizacji wymaga budowania akceptacji i zrozumienia, przede wszystkim wśród mieszkańców terenów rewitalizowanych. Dlatego też konieczne jest połączenie systemu okresowej aktualizacji programu z systemem public relations i systemem komunikacji społecznej. Umożliwi to świadome i systematyczne zarządzanie procesami komunikacji pomiędzy władzami lokalnymi a wszystkimi podmiotami i osobami, czynnie oraz biernie związanymi z programem rewitalizacji. W praktyce oznacza to kreowanie akceptacji i zrozumienie dla nowych rozwiązań oraz budowę i rozwijanie zaufania lokalnej społeczności wokół realizowanych zadań i projektów ${ }^{23}$.

\footnotetext{
${ }^{23}$ T. Markowski, D. Stawasz, A. Nowakowska, Plan systemu okresowej...
} 